Jpn. J. Med. Mycol.

Vol. 34, 243-251, 1993

ISSN $0916-4804$

総説

ミトコンドリア DNA 分析による真菌の分類

石崎宏

金沢医科大学皮用科学教室

要 旨

Sporothrix schenckii と Ceratocystis stenoceras, 皮店系状菌, 黒色真菌についてミトコンドリ ア DNA（mtDNA）分析を行った。本邦の S. schenckii は mtDNAの制限酵素切断パターンから 11 タイプに分けられ，またタイプと分離地域とに関連がみられた. さらにS. schenckii は C. stenoceras とは極めて近縁であるが別種であることが明らかとなった. 皮咸系状菌では異なった種が同一の切断パ ターンを示す例があり，糸状菌の分類は分け過ぎで再検討の必要が示唆された. Exophiala jeanselmei は断片サイズの多様性から種としてまとめられず, complex と考えられた．またExophiala moniliaeの一部は $E$. jeanselmei の一部と同一の切断パターンを示し, E. moniliaeの独立性につ いて疑問が示唆された. 一方, Exophiala dermatitidis は全株とも同一の切断パターンを示した.

Key words : ミトコンドリア DNA (mitocondria DNA), 制限酵素切断パターン (restriction pattern), 系統樹 (phylogenetic tree), 分類 (taxonomy), 分子疫学 (molecular epidemiology)

はじめに

真菌の分類, 同定は主に形態, 生理, 化学的特 徴に基づいてなされてきたが,これらの方法には 限界があり，未解決の問題も少なからず残されて いる. 近年，ミトコンドリアDNA（mtDNA）分 析が真菌の分類・同定, 系統発生の研究に用いら れ，新しい知見が加えられつつある 1-6). mtDNA のサイズは比較的小さいため DNA 全体を検討す ることができ，また mtDNA はゲノム DNAに比 べて変異率が約 10 倍高く, 従って mtDNA 分析 はそれだけ真菌の分類, 進化の過程の研究に有利 で，とくに近縁関係にある菌種の比較検討に適し ていると考えられる7).ここでは金沢医科大学皮 膚科で行った若干の病原真菌の mtDNA 分析によ る同定, 分類, 系統樹作成, 疫学調査などの成績 を述べる。

別刷請求先 : 石崎 宏

干920-02 石川県河北郡内灘町大学 1-1 金沢医科大学皮间科学教室

\section{Sporothrix schenckii}

mtDNA の制限酵素切断パターンによるタイプ分 類および切断パターンを基にして作成した mtDNA タイプの系統樹，さらに分離地域と mtDNA タイ プ，系統樹との関連について検討した 8,9 .

材料として本邦の東北, 関東, 北陸, 東海, 関 西, 九州の 6 地方で臨床分離された S. schenckii 280 株を用いた。

mtDNAの分離方法は以下の如く行った. $S$. schenckiiをサブロー液体培地で室温， 1 週間の振 盪培養後，遠心により菌体を得る. 菌体を 2 -メル カプトエタノール，ザイモリエース 100-T 処理後， 超音波ホモジナイザー処理, $1,600 \mathrm{~g} 10$ 分間の遠心 により得られた上清を $20,000 \mathrm{~g} 10$ 分間の遠心にか け，ミトコンドリア画分を得た。つぎにミトコン ドリア画分にSDSを加え，フェノール抽出し，透 析，エタノール沈澱により mtDNAを得る。これ ら 280 株の各 mtDNA について制限酵素切断パター ンを検討した。 


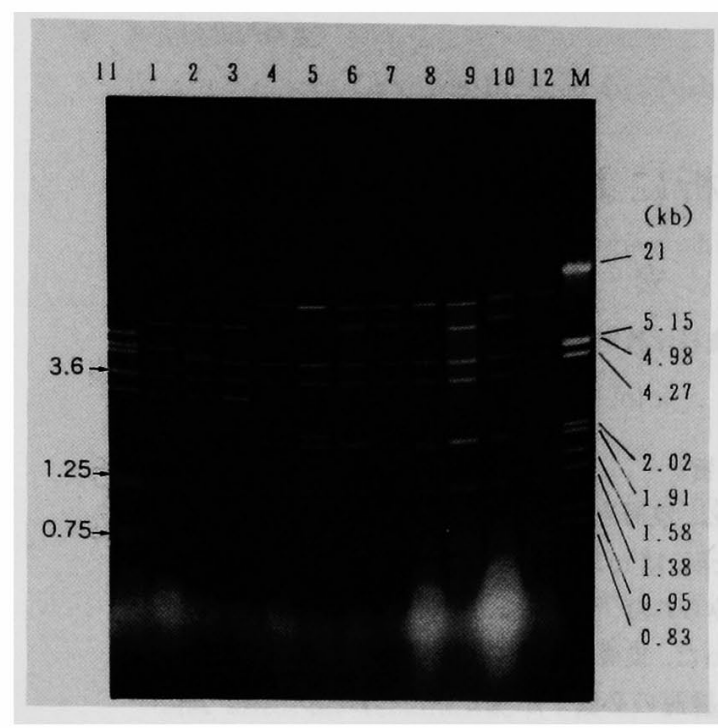

Fig. 1. Restriction profiles of $S$. schenckii mtDNA digested with Hae III. Lanes 1 to 12 : mtDNA types 1 to 12 . Lane $\mathrm{M}$ : size marker.

その結果, 本邦のS. schenckii は mtDNA の Hae III 切断パターンで 11 タイプ (タイプ1〜10, 12) に分けられた (Fig. 1) (タイプ11はフランス株). 全てのレーン (タイプ) で3.6, $1.25,0.75 \mathrm{kbp}$ の 共通バンドが見られた. さらにこれら HaeIIIによ る各タイプの菌株について制限醭素 MspI, Hind III, $B g l \mathrm{II}, X b a \mathrm{I}$ 切断パターンをみると, $M s p \mathrm{I}$ で はHaeIII タイプ 4 と 8 の菌株は同一のパターンを 示した。同様にタイプ 5 と 12 , タイプ $6,7,9$, 10 の菌株もおのおの同一パターンを示した. Hind III では HaeIII タイプ 4 と 8, タイプ 5 と 12 , タイ プ 6 と 8 の菌株はおのおの同一パターンを示した. BglII では HaeIII タイプ 4, 8, タイプ 5 と 12, 夕 イプ $6,7,9,10$ の菌株はおのおの同一パターン を示した. XbaI では HaeIII タイプ 4 と 8, タイプ 5 と 12 , タイプ 6 と 8 の菌株はおのおの同一パター ンを示した. 以上より本邦のS. schenckii 株はHae III切断パターンで 11 タイプに分類され, またS. schenckii は全タイプ共通の 3 本のバンドにより 同定され得ることが判明した。

\section{Ceratocystis stenoceras}

本菌は S. schenckii の teleomorph ではなかろ うかとされ, 多くの研究者により検討されて来た.
これまでのところC. stenoceras はS. schenckii とは近縁であるが teleomorph ではないとする意 見が有力である.ここでは C. stenoceras 17 株に ついて mtDNAの制限酵素による切断パターンを 比較検討した. C. stenoceras は HaeIII切断パター ンに基づいて 4 タイブに分けられ，また 1.25 およ び $0.75 \mathrm{kbp}$ のバンドを S. schenckii と共有するが, 3.6kbpのバンドを欠くことでS. schenckii とは区 別された. すなわち C. stenoceras は S. schenckii と極めて近縁であるが, S. schenckiiの teleomorph ではないことが明らかとなった. なお最近 Cooper ら10)は C. stenocerasの1タイプを追加している.

\section{3. 異なった mtDNA タイプ菌株の混合}

従来の形態学的方法では異なったタイプの S. schenckii あるいは C. stenoceras 菌株の混合を発 見することは不可能である. しかし，異なった夕 イプの混合菌株の mtDNA 切断パターンは各タイ プの切断パターンの重なりとして表現され, 発見 が可能となる.

Fig. 2 は. schenckii 臨床分離株での実例を示 したものである.レーン1はスポロトリコーシス の病巣より分離された原菌株の切断パターンで, タイプ 2 とタイプ 6 の重なりからなると考えられ る. レーン 2 以下のレーンは原菌株を単胞子培養 し, 得られた各コロニーの切断パターンを示す. レーン 2 の切断パターンはタイプ 2, レーン 4 の それはタイプ 6 に合致し，またレーン 6 のそれは レーン 1 のそれと同一で, このレーン 6 のコロニー が未だ混合株であることを示している. 以上より 同一病巣内に複数の菌株が存在し得ることが明ら かとなった.ささに同一患者で異なった病巣より 異なったタイプの菌株が分離されることもある11). すなわちスポロトリコーシスは同一症例で複数の 異なった菌株の感染によって生じ得ることが明ら かにされた訳である.

Fig. 3 は C. stenoceras の HaeIII による切断パ ターンを示したものであるが, C-III のパターンは C-I と C-IV のそれの重なりと考えられる．そこで C-III 株を単胞子培養し, 各コロニーから得た mt DNA 切断パターンをみると, C-III 株は C-I と C-IV 株のパターンを示す株に分けられた。この菌株は オランダの CBS 由来（CBS146.71）であり，保存 施設の菌株にも混合のあり得ることが示された訳 


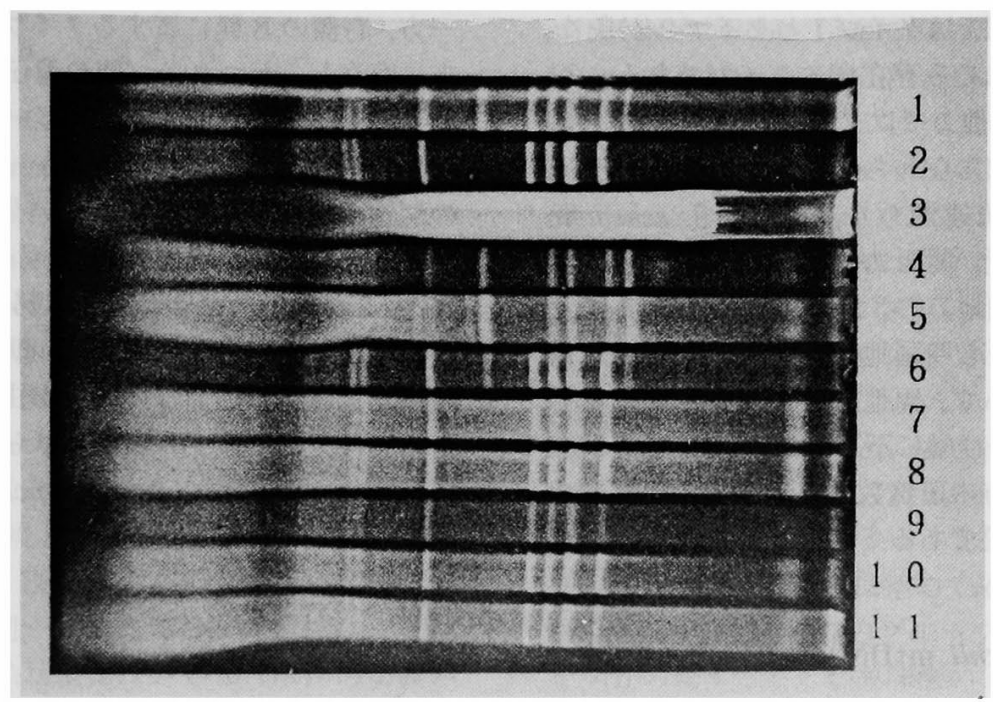

Fig. 2. Restriction profiles of S. schenckii mtDNA digested with HaeIII. Separation of each S. schenckii strain from a colony composed of two different mtDNA types. Lane 1 : original colony before separation showing doubling of type 2 and type 6 profiles. Lanes 2 to 11 : profiles of each colony after single spore culture of original colony. Profiles of Lanes 2,7 11 correspond to type 2. Profiles of Lanes 4 and 5 correspond to type 6 . Lanes 6 and 1 show identical profiles, indicating the colony of Lane 6 is still not separated.

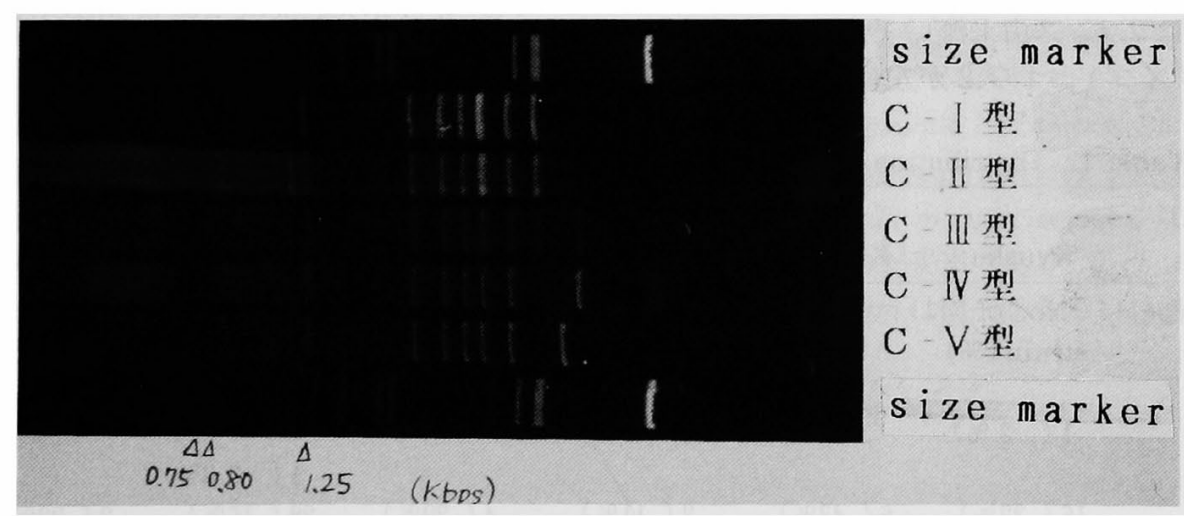

Fig. 3. Restriction profiles of C. stenoceras mtDNA digested with Hae III. Lane C-III is suggested to be doubling of Lanes C-I and C-IV, indicating that the colony of $\mathrm{C}$-III is a complex one.

である．以上より実験に用いる菌株については, 予め本法を用いて混合の有無を確認する必要があ ろう.

\section{S. schenckii の分子疫学}

Table 1 は前述の 6 地方と S. schenckii の $\mathrm{mt}$ DNA タイプとの関係を示す.これから，1）九州お よび関西地方ではタイプ 4 とタイプ 6 の比率が高 
い, 2 ) 北陸地方ではタイプ 1 とタイプ 2 が多く, タイプ 1 は北陸にのみ存在するタイプである．3） 東海, 関東, 東北地方ではタイプ 5 が多いなどの 特徴が窥われる.すなわちS. schenckiiの mtDNA タイプと地域に関連があり，本邦の S. schenckii の分布は 1 ）九州, 関西地方，2）東海, 関東, 東 北地方，3）北陸地方の 3 地域に大別されること が示された.ただし四国地方，山陰地方の菌は未 だ検討されておらず，両地方の分布の解明は本邦 のS. schenckii の疫学に不可欠である.また関東 地方以外他の地方の菌株数は不十分で, 引き続き 今後の検討が必要である.ささらに新たなタイプの 発見も予想される.

\section{S. schenckii mtDNA タイプの系統樹}

本邦の 11 タイプ, フランス由来株の 1 タイプ計 12 タイプの各制限酵素HaeIII, MspI, HindIII, $B g l \mathrm{II}, X b a \mathrm{I}$ 切断パターンから, Nei \& Li の計算 法12）に基づいて各タイプの塩基置換率をコンピュー ターを用いて推計し，さらにFitch \& Margoliash の方法13)によって系統樹を作製した (Fig. 4).こ れによれば本邦の S. schenckii は系統樹の左側に 位置するタイプ 1，2，3の A 群と右側の残りの タイプからなる B 群の 2 群に大別される（なお， タイプ11 はフランス由来株).そして北陸地方に 特徴的なタイプ 1 および 2 が左側の $\mathrm{A}$ 群に属し，
一方, 右側の B 群に属するタイプは北陸以外の地 方に存在し，かつタイプ間の遗伝的距離も近いこ と, すなわち同一地方内では互いに近縁のタイプ が集まることが示される。現在，A，B群と地域と の関連を説明できる証拠はない. しかし東海, 関 東, 東北地方でタイプ 5 が多い, 北陸地方でタイ プ 1，2 が多いという事実は本邦のS. schenckiiの 由来と係わる興味深い問題で, 朝鮮半島や中国大 陸など近隣地域の菌株の検討が由来の解明への手 掛りを与えるかも知れない. さらに世界のS. schenckiiについて検討し, S. schenckii の起源を明ら かにしたいと考えている。

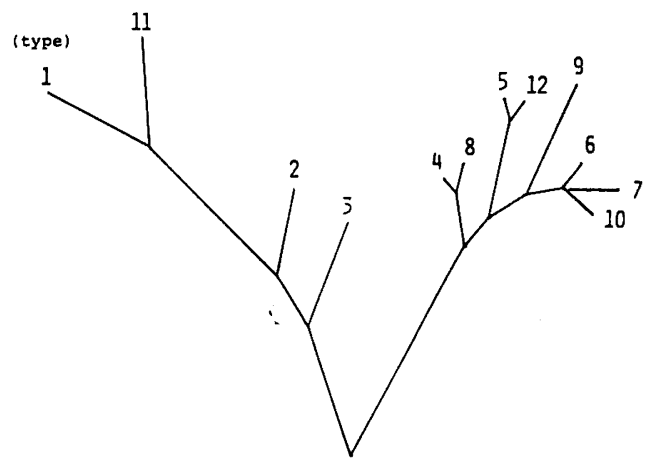

Fig. 4. Phylogenetic tree of mtDNA types of S. schenckii.

Table 1. Distribution of mtDNA types of S. schenckii from six districts in Japan

\begin{tabular}{|c|c|c|c|c|c|c|}
\hline & \multicolumn{6}{|c|}{ Districts } \\
\hline & Kyushu & Kansai & Hokuriku & Tokai & Kanto & Tohoku \\
\hline Type & $\begin{array}{c}\text { No. of } \\
\text { strain }(\%)\end{array}$ & & & & & \\
\hline 1 & & & $3(16 \%)$ & & & \\
\hline 2 & $1(2 \%)$ & & $9(47 \%)$ & & & \\
\hline 3 & & & & & $1(0.6 \%)$ & \\
\hline 4 & $16(32 \%)$ & $6(43 \%)$ & $2(11 \%)$ & $4(29 \%)$ & $28(16 \%)$ & $2(22 \%)$ \\
\hline 5 & $8(16 \%)$ & $1(7 \%)$ & $1(5 \%)$ & $7(50 \%)$ & $140(80.5 \%)$ & $6(67 \%)$ \\
\hline 6 & $10(20 \%)$ & $5(36 \%)$ & $3(16 \%)$ & $1(7 \%)$ & $4(2.3 \%)$ & $1(11 \%)$ \\
\hline 7 & $11(22 \%)$ & & $1(5 \%)$ & $1(7 \%)$ & $1(0.6 \%)$ & \\
\hline 8 & & $1(7 \%)$ & & & & \\
\hline 9 & $3(6 \%)$ & $1(7 \%)$ & & & & \\
\hline 10 & $1(2 \%)$ & & & & & \\
\hline 11 & & & & & & \\
\hline 12 & & & & $1(7 \%)$ & & \\
\hline Total & $50(100 \%)$ & $14(100 \%)$ & $19(100 \%)$ & $14(100 \%)$ & $174(100 \%)$ & $9(100 \%)$ \\
\hline
\end{tabular}




\section{6. 皮虎系状菌}

1987 年パスッール研究所の de Bievre ら 14) は Trichophyton rubrum について 2 種の mtDNA 切断パターンを報告した. 1990 年 Mochizuki ら 15) は T. interdigitale (mentagrophytes var. interdigitale), Arthroderma simii, A. benhmiae, A. vanbreuseghemii mtDNA の制限酵素 HaeIII, Msp I, HindIII による切断パターンを検討し, T. interdigitale と A. vanbreuseghemii が同一の切断パ ターンを示したことより，この両者は極めて近縁 であることを示唆した。ささらに $T$. interdigitale のパターンが de Bievre ら 14)のT. rubrum のパ ターンの 1 つと同一であることが判明した.

ここでは皮膚系状菌について mtDNAの切断パ ターンの検討, 系統樹作製を行った16). 金沢医科 大学病院皮膚科で臨床分離された T. rubrum 92 株, およびT. mentagrophytes var. mentagrophytes 2 株 (CBS 263.70, 570.80), T. mentagrophytes var. erinacei (CBS344.79), T. mentagrophytes var. goetzii 2 株 (CBS 426.70, 845.73), T. mentagrophytes var. interdigitale 2株 (CBS 232.76, 343.79), T. quinckeanum 2 株 (CBS 106.67, 572.75), T. shoenleinii 2 株 (CBS 435.63, 855.71), T.tonsurans (CBS 249.74), T. verrucosum var. album 2 株 (CBS 161.66, 526.50), T. verrucosum var. discoides 2 株 (CBS 365.53, 460.59), T. violaceum var. violaceum (CBS 555.84), Arthroderma benhamiae (RV 26678), A. vanbreuseghemii (RV 27960), (CBS : Centraalbureau voor Schimmelcultures, Baarn, Netherlands. RV:In- stitut de medicine Tropicale, Antwerp, Belgium) について mtDNA の制限酵素 HaeIII, MspI, Hind III, XbaI, BglII 切断パターンを検討した.

その結果, T. rubrum の HaeIII 切断パターンは de Bievre ら 14)の報告した2種の HaeIII 切断パター ンと一致し, T. rubrum は 2 タイプ・(タイプI, タ ・イプII）に分けられた，さらに今回検討された菌 種は切断パターンの違いに基づいて 6 タイプに分 けられるとともに, T. rubrum タイプ II, T. m. var. interdigitale, T. m. var. goetzii, T. tonsurans, T. quinckeanum, T. schoenleinii, A. vanbreuseghemii は同一パターンを示し, このグルー プの菌種は同一あるいは極めて近縁にあることが 示唆された.とくにこのグループにT. rubrum夕 イプII の属することが興味深い.また $M s p$ I 切断 パターンでもHaeIII と同様に 6 タイプに分けら れた. 一方, HindIII, BglII, XbaI を用いるとA. vanbreuseghemii や T. rubrum タイプII のグルー プに属するT. quinckeanum, T. schoenleinii は 切断パターンの違いによりグループから分けられ た.

以上，最終的に 7 タイプに分けられた皮膚系状 菌について, 前述の方法で系統樹を作成した（Fig. 5).この系統樹から，1）A. benhamiaeはA.vanbreuseghemii よりむしろ T. m. var. erinacei や T. rubrum タイプIに近い. 2) T. tonsurans は A. vanbreuseghemii と同一かあるいは極めて 近縁にあり，T. mentagrophytes の亜種としてよ いであろう. 3) T. m. var. erinacei は独立種 $T$. erinacei とするのが妥当である.4) T. schoenlenii とT. quinckeanum は同一かあるいは極めて近縁

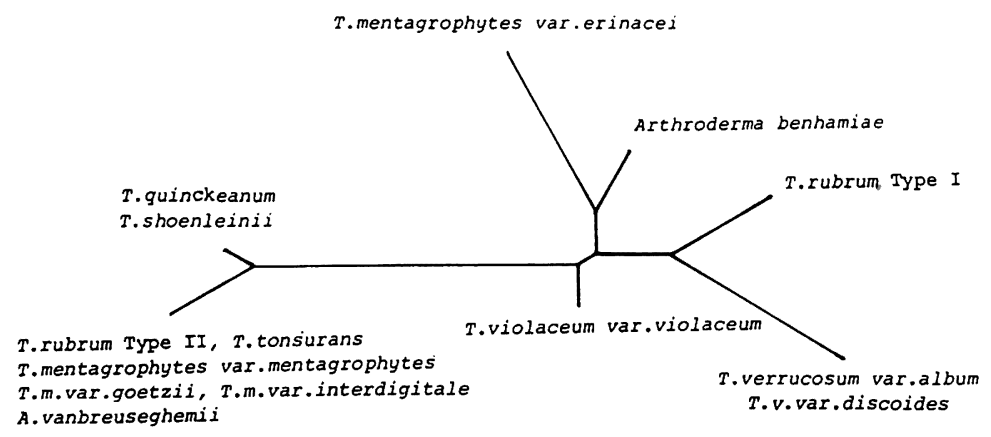

Fig. 5. Phylogenetic tree constructed from sequence divergences of mtDNA of dermatophytes. 
にあり，両者ともT. mentagrophytes の亜種とし てよい, などの点が示唆される，5）しかし最も 重要かつ興味ある点は T. rubrum夕イプ山とA. vanbreuseghemii との関係である。T.rubrum 夕 イプII と A. vanbreuseghemii，を同一あるいは極 めて近いものとすれば, T. rubrum の同定法の再 評価が必要となる。著者はこの考えに賛成で, 実 際には T. mentagrophytęsの一部が.T. rubrum とされているのではなかるうか. その他, 切断パ ターンを用いれば䋐毛変性した菌株でも同定可能 である。

次に T. rubrum 92 株の夕イプとコーンミール 培地上の色素産生との関係をみると, 色素産生株 51.株（タイプI 51 株，タイプ II 0)，色素非産生 株 41 株（タイプI 13 株, タイプ II 28 株）となり, 色素産生株にタイプII はなく, 色素非産生株には 両タイプが含まれる。すなわち色素産生株は夕イ プIとしてよいが, 非産生株には両タイプが混じ ることより，T. rubrum タイプII を T. mentagrophytes と同一とすれば T. rubrum タイプIの色 素非産生株では T. mentagrophytes との鑑别は mtDNAの切断パターンによる必要がでてくる.

\section{T. rubrum と T. raubitschekii}

T. raubitschekii は T. rubrum と酷似するが, 1) ウレアーゼ陽性，2）ラクトース寒天培地で発育 が制限される゙，3）カゼイン・デキストロース寒 天培地で色素は褐色, および 4) 大分生子を豊㾇 に作ることなどで T. rubrum とは異なるとさ如て いる17). そこでT. raubitschekii ATCC 42631, 64392, 64653の 3 株について HaeIII, MspI, Bgl II, Hind III による mtDNAの制限酵素切断パター ンを検討したところ，T. rubrum タイプIのそれ と同一であった：以上よりT. raubitschekii の特 徵は T. rubrum の種内変異内のもので, 本菌を独 立種とする必要がないと考えたい.

\section{T. violaceum と T. glabrum}

両菌種の異同については同一種とする意見が有 力である. そこでT. violaceum 3 株, T. glabrum 2 株について mtDNA の HaeIII, MspI, BallI 切 断パターンを検討したところ, 両菌種のパターン は同一で，同一種とする説を支持する結果が得ら れた。

\section{Arthroderma 属と Nannizzia 属}

Trichophyton 属および Microsporum 属の teleomorph はそれぞれ Arthroderma, Nannizzia 属 とされてきたが, Weitzmanら18)は両属を統一す る考えを提唱している. Kawasaki ら ${ }^{19)}$ はArthroderma 属の $A$. benhamiae, $A$. insingulare, $A$. quadrifidum, A. simii, A. vanbreuseghemii $ら$ 5 種, Nannizzia 属の N. fulva, N. grubyia, N. gypsea, $N$. incurvata, N. otae 55 種の計 10 種 について mtDNA の HaeIII, HhaI, MspI, BglII, EcoRI，EcoR V, Hind III, XbaI 切断パターンを 検討し, 系統樹を作成した。これによれば 10 種は 近縁関係よりおのおのの属にまとめられず互いに 入り混じり，両属間に明確な線引きができず， 1 つの属Arthrodermaに統一するのが妥当と考え られ，Weitzman ら 18)の意見を支持する成績が得 られた。

\section{Exophiala jeanselmei と Exophiala dermatitidis}

E. jeanselmei は McGinnis \& Padhye 20)によ り Phialophora jeanselmei およびP. gougerotî を統一して命名されたものであるが, 菌株間の差 異が大きいことより，本菌を complex とする意見 が有力である.またE. dermatitidis は形態的に E. jeanselmeiに似ている.

ここでは P. gougerotii 15 株, P. jeanselmei 30 株, E. dermatitidis 31 株について制限酵素 Hae III, Hind III, MspIによる mtDNA 切断パターン を検討した21). その結果, P. gougerotii とP. jeanselmeiの 45 株はHaeIII 切断パターンに基づいて 15タイプに分けられ，そのうち 8 タイプで両菌種 が含まれていた. またHind III, Msp II による切断 パターンの組み合せで最終的に18タイプに分け られた。しかし本菌では全タイプ間に共通するバ ンドがないことより，1種としてまとめるのは困 難で，本菌を complex とするのが妥当と考えられ た. 従って, E. jeanselmei の新たな分類基準が求 められる.一方, E. dermatitidisは全株とも同一 の切断パターンを示し, 種内変異はみられなかっ た. 以上より，E. dermatitidisは mtDNAの切断 パターンから E. jeanselmei とは明確に区別され るとともに, mtDNAの切断パターンはE.dermati- 
tidisの同定に有用と考えられた.

\section{Exphiala jeanselmei と Exphiala moniliae との関係}

E. moniliae は 1977 年 de $\mathrm{Hoog}^{22)}$ により新しい 種として記載されたが, E. jeanselmei と形態的に 酷似する.ここでは E. moniliae 17 株について mtDNA の制限酵素 HaeIII, HindIII, MspIによ る切断パターンを検討した ${ }^{23)}$. その結果, E. moniliaeは10タイプに分けられ，また全タイプ間に共 通のバンドがなく, E. jeanselmei と同様に mtDNA の断片サイズの著しい多様性から種としてまとめ られなかった. さらにE. moniliaeの 2 タイプは E. jeanselmei の 2 タイプと同じ切断パターンを示 すなど切断パターンで E. moniliae は E. jeanselmeiより区別され得ず, E. moniliae の形態的特 徵は別種の根拠とはならないことが示唆された。 E. moniliaeの分類は E. jeanselmei と同様に再検 討の必要があると考えられる.

\section{Cladosporium carrionii の分子疫学}

アフリカ（マダガスカル，モザンビーク，ウガ ンダ各 1株)，オーストラリア (10株)，中国 (15 株), ベネズエラ (10株) で分離されたC. carrionii 38 株について mtDNA の HaeIII, MspI, Sau3 AI 切断パターンを検討し, 本菌は 4 タイプ（タイプ IＩV）に分けられた. またこの切断パターンは, E. jeanselmei, E. moniliae, Phialophora spinifera, P. verrucosa, Fonsecaea pedrosoi, Hortaea werneckii などのそれとも異なり，C. carrionii 切断パターンで同定できることが明らかとなった. さらにタイプIはべネズエラの 10 株中 9 株と中国 の 15 株中全株およびウガンダの 1 株, タイプ II はオーストラリアの 10 株中全株とマダガスカル 1 株, タイプIII はモザンビークの 1 株, タイプIVは ベネズエラの 10 株中の 1 株でみられ, C. carrionii のタイプと分離地域に関連がみとめられた.

以上より本菌の分布について以下の推論を試み た. すなわち本菌のアフリカの 3 株がおのおの夕 イプI, II, III を示したことより，本菌はアフリカ で発生し, かつ種内変異を生じた。 ついで大陸移 動にともない世界各地へと分布域が拡大し, 最終 的に本菌の生存に適した地域, すなわち乾燥地域 でのみ生き残ったのではなかろうか. 本菌が中国
では山東省などの降雨量の少ない乾燥地域でのみ 発見される理由は他の地域では本菌は生き残れな かった為であろう。タイプIがたがいに遠く離れ た中国とベネズエラに存在する理由も同様に説明 されよう.またオーストラリアのタイプII 株はア フリカより南極大陸を介したものであろう．さら にベネズエラのタイプIV株がアフリカで発見さ れれば,この推測に有利である。この意味でアフ リカの分離株の検討が今後の重要な課題である. 最後に本邦では C. carrionii は未だ発見されてい ないが, かつては存在したのではなかろうか. そ して若し発見されるならば本邦の降雨量の少ない 地域においてであり，菌株はタイプIであろう.

\section{文献}

1) Kozlowski M, Stepien PP : Restriction enzymes analysis of mitochondrial DNA of member of the genus Aspergillus as an aid in taxonomy. J Gen Microbiol 128 : 471-476, 1982.

2) Garber RC, Yoder, OC: Mitochondrial DNA of the filamentous ascomycete Cochliobolus heterostrophus. Curr Genet 8:621 $-628,1984$.

3) Specht CA, Novotny CP, Ullrich RC: Isolation and characterization of mitochondrial DNA from the basidiomycete. Schizophyllum commune. Expt Mycol 1:336 $-343,1983$.

4) Kistler HC, Bosland PW, Benny U, Leong $\mathrm{S}$, Williams $\mathrm{PH}:$ Relatedness of strains of Fusarium oxysporum from crucifers measurd by examination of mitochondrial and ribosomal DNA. Phytopathology 77 : 1289-1293, 1987.

5) Foerster H, Kinscherf TG, Leong, SA, Maxwell DP : Estimation of relatedness between Phytophthora species by analysis of mitochondrial DNA. Mycologia $80: 466$ $-478,1988$.

6) Foerster H, Kinscherf TG, Leong SA, Maxwell DP : Restriction fragment length polymorphisma of the mitochondrial DNA of Phytophthora megasperma isolated from soybean, alfalfa, and fruit trees. Cand $\mathrm{J}$ Bot 67 : 529-537, 1989.

7) Taylor JW : Fungal evolutionary biology and mitochondrial DNA. Exp Mycol 10: 259-269, 1986. 
8) Suzuki K, Kawasaki M, Ishizaki H : Analysis of restriction profiles of mitochondrial DNA from Sporathrix schenckii and related fungi. Mycopathologia 103 : 147-151, 1988.

9) Takeda Y, Kawasaki M, Ishizaki H : Phylogeny and molecular epidemiology of Sporothrix schenckii in Japan. Mycopathologia 116 : 9-14, 1991.

10) Cooper CRJr, Breslin BJ, Dixon DM, Salkin IF : DNA typing of isolates associated with the 1988 sporotrichosis endemic. J Clin Microbiol 30 : 1631-1635, 1992.

11) Kobayashi H, Kawasaki M, Fukushiro R, Matsumoto $\mathrm{R}: \mathrm{A}$ case of sporotrichosis caused by two genetically different Sporothrix schenckii strains. Mycopathologia 112 : 19-22, 1990.

12) Nei $M$, Li WH: Mathematical model for studying genetic variation in terms of restriction endonucleases. Proc Natl Acad Sci USA 76 : 5269-5273, 1979.

13) Fitch WM, Margoliash E : Construction of phylogenetic trees. Science $155: 279-284$, 1967.

14) de Bievre $C$, Dauguet $C$, Nguyen VH, Ibrahim-Granet $\mathrm{O}$ : Polymorphism in mitochondrial DNA of several Trichophyton rubrum isolates from clinical specimens. Ann Inst Pasteur/Microbiol 138 : 719-727, 1987.

15) Mochizuki T, Takada $K$, Watanabe $S, K a-$ wasaki M, Ishizaki H : Taxonomy of Trichophyton interdigitale ( Trichophyton mentagrophytes var. interdigitale) using restriction enzyme analysis of mitochon- drial DNA. J Med Vet Mycol $28: 191-196$, 1990.

16) Nishio $K$, Kawasaki $M$, Ishizaki $H$ : Phylogeny of the genera Trichophyton using mitochondrial DNA analysis. Mycopathologia 117 : 127-132, 1992.

17) Kane J, Salkin IF, Weitzman I, Smitka C : Trichophyton raubitschekii. Sp Nov Myco taxon 13 : 259-266, 1981.

18) Weitzman I, McGinnis MR, Radhye AA. Ajello L : The genus Arthroderma and its later synonym Nannizzia. Mycotaxon 15 : 505-518, 1986.

19) Kawasaki $M$, Aoki $M$, Ishizaki $H$, Nishio K, Mochizuki T, Watanabe S : Phylogenetic relationships of the genera Arthroderma and Nannizzia inferred from mitochondrial DNA analysis. Mycopathologia 118 : 95102, 1992.

20) McGinnis MR, Padhye AA : Exophiala jeanselmei, a new combination of Phialophora jeanselmei. Mycotaxon 5 : 341-352, 1968.

21) Kawasaki $M$, Ishizaki $H$, Nishimura $K$, Miyaji M:Mitochondrial DNA analysis of Exophiala jeanselmei and Exophiala dermatitidis. Mycopathologia 110 : 107-112, 1990.

22) de Hoog GS:Rhinocladiella and allied genera. In: Studies in Mycology No15 pp 1-140, 1977.

23) Kawasaki $M$, Ishizaki $H$, Nishimura $K$, Miyaji $\mathrm{M}$ : Mitochondrial DNA analysis of Exophiala moniliae. Mycopathologia 121 : 7-10, 1993. 


\title{
Fungal Taxonomy Based on Mitochondrial DNA Analysis
}

\author{
Hiroshi Ishizaki \\ Department of Dermatology, Kanazawa Medical University, \\ Uchinada, Ishikawa 920-02, Japan
}

- Mitochondrial DNA (mtDNA) analysis was performed in Sporothrix schenckii, Ceratocystis stenoceras, dermatophytes, and dematiaceous fungi.

$S$. schenckii in Japan was classified into 11 types based on mtDNA restriction patterns, with a relationship found between type and geographical origin.

$S$. schenckii proved to be closely related, but not identical to $C$. stenoceras. Some species of dermatophytes revealed identical restriction patterns, suggesting overclassification of dermatophytes. Exophiala dermatitidis has no intraspecific variation, while Exophiala jeanselmei is suggested to be a complex organism because of extensive mtDNA polymorphism. Restriction patterns of some strains of Exophiala moniliae were identical to those of $E$. jeanselmei, suggesting that the taxonomic status of $E$. moniliae requires reevaluatation.

この論文は，第36回日本医真菌学会総会の教育講演として発表されたものです. 